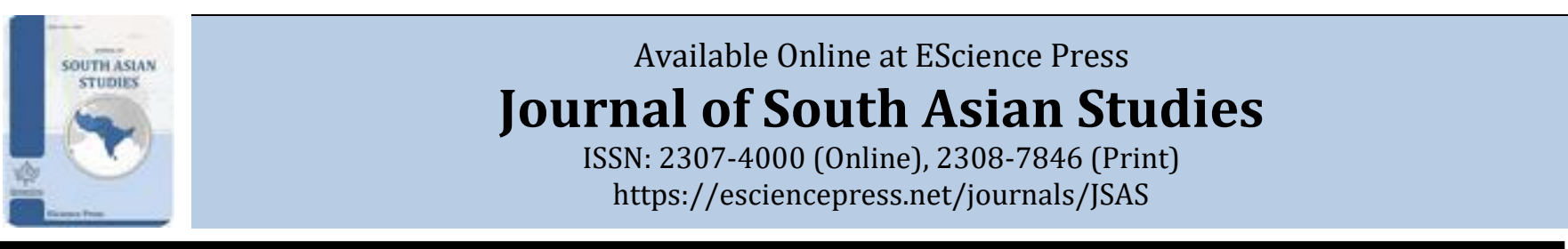

\title{
Appraisal of Order in ASEAN and SAARC: A Comparative Inquiry
}

\author{
aMohammad Ali Zafar*, aShaheer Ahmad \\ a Department of International Relations, National Defence University, Islamabad, Pakistan.
}

*Corresponding Author Email ID: alizafar100y@yahoo.com

A B S T R A C T

The paper examines how ASEAN has emerged as a face of Southeast Asia from anarchy to order, to promote stability, strengthen sovereignty, reduce the role of great powers, and build the harmony of interests among the states, while SAARC remained less effective in maintaining order in South Asia. While combating the challenges of communism and regional instability, ASEAN has minimized the involvement of non-state actors, keeping the state's sovereignty at the forefront. On the other hand, SAARC remained less influential in maintaining order under common norms, values, and failed to build an effective conflict resolution mechanism. SAARC remained ineffective in solving inbuilt hostility between India and Pakistan. To understand the reason for the effectiveness of ASEAN vis-à-vis SAARC, the conceptual framework of order proposed by Hedley Bull provides a befitting context to examine both regional platforms. Hence, the paper will comparatively analyze how and why ASEAN has performed better than SAARC in conflict management. Eventually, the paper discusses the possible changes that SAARC can make to maintain order in South Asia.

Keywords: Order, ASEAN, SAARC, South Asia, Southeast Asia.

\section{INTRODUCTION}

States existing in a common regional space often conflict with one another rather than cooperate. The presence of conflicts not only affect the conflicting states but also makes the entire region unstable. This situation calls for a desire to create an institutional framework that upholds the order. It includes the binding rules, norms and institutions that depict the trade-off states are going to make. Based on this, the European Union emerged as a supranational authority, which remains not the case in the formation of ASEAN and SAARC in the Southeast and South Asian region, respectively. ASEAN and SAARC were formed on the primary interest of safeguarding the sovereignty of regional members. However, the interests of ASEAN varied due to its eagerness to reduce the intraregional conflicts, combat communism, bringing internal cohesion, and avoid the region being devoid of a regional entity.

ASEAN's regional order formation allowed the member states to establish their unique characteristics and norms under a common framework. The emergence of ASEAN as a face of Southeast Asia moved the region from anarchy to order, strengthened states' sovereignty, and reduced the role of great powers from the region. Constituent elements, such as common interests, norms, and diplomacy, indicating that ASEAN's regional order is established within the conceptual framework of order. On the other hand, SAARC was established with a similar aim as that of ASEAN; however, it remained less successful than ASEAN due to its disregard to promote regionalism. It remained on the back foot due to the lack of consensus among the members, inter-state conflicts, Indo-centric threat perceptions, lack of cooperation, the existence of vast tapestry of cultures, absence of the platform solving the contentious bilateral issues and lack of conflict resolution mechanism. Moreover, SAARC's presence hasn't prevented and resolved the occurrence and management of the conflicts. In comparison with ASEAN, SAARC has yet to promote regionalism to build the trust of its members and use the forum to solve interstate conflicts efficiently.

The paper argues that ASEAN has been more effective than SAARC in upholding regional security and order. Therefore, the study is divided into four parts. The first 
part includes the theoretical framework, which elaborates on how and why ASEAN emerged as an example of what Hedley Bull called to order. At the same time, SAARC remained on the back foot to reach the expectations. The second part discusses that how the Southeast Asian region moved from anarchy to order. It includes the discussion on the formation of ASEAN and its functioning during the post-cold war era. The third part draws a comparative inquiry between ASEAN and SAARC. The fourth part evaluates the factors determining the effectiveness of ASEAN and SAARC. The last part concludes the study by providing recommendations for SAARC to imply the structural changes which will enhance the faith of member states in SAARC.

\section{LITERATURE REVIEW}

Hedley Bull and Andrew Hurrell (2012) have defined the concept of 'Order' and its three aspects of maintaining order. Adam Watson (1992) has explained the rules and norms of English School in the system of sovereign states. Jorgensen Dahl (1982) discusses the anarchic environment and the threat of communism in the Southeast Asia. Robin Ramcharan (2000) discusses the maintenance of the ASEAN's principle of noninterference in the internal affairs of member states. Smruti S. Pattanaik (2006) has argued about the reason that why SAARC has been modest and not been able to achieve its goals. Sujan Amgain (2016) has discussed the Indian hegemonic aspirations in South Asia due to its attributes of geography, size, economy and power. Zhan Yunling (2017) has discussed the successes of ASEAN in achieving the unity, stability, peace and economic prosperity. Kripa Sridahran (2008) compares the role of ASEAN and SAARC in managing the interstate conflicts in their regions. It has discussed the effectiveness of ASEAN in enhancing the regional security and weakness of SAARC in promoting the regionalism.

Available literature on this topic explores the order approach in ASEAN, in which it discusses that how ASEAN emerged as a face of Southeast Asia by promoting stability, strengthening sovereignty, reducing the role of the great powers, and building harmony among the states. Meanwhile, the literature also discusses that why SAARC didn't reap the benefits of the regionalism as ASEAN did. A perfunctory review of the available literature analyzes the ASEAN and SAARC in ensuring peace, stability and managing the conflicts in their respective regions. However, the part that has been largely ignored is the implication of a coherent theoretical approach like Hedley Bull's concept of 'order', more specifically in the comparative inquiry of both organizations. For instance, this particular paper inquires both organizational entities through the theoretical approach of Hedley Bull which has largely been ignored in the existing literature, which only lies on the policy papers and common perceptions. Hence, the study provides a new lens to view the regionalism in South and Southeast Asia.

\section{RESEARCH METHODOLOGY}

The qualitative research employs content analysis to analyse methods by taking relevant insights from the existing literature. In this study, research articles, published books, newspapers, magazines, different websites and official documents are considered as the secondary sources of data used.

\section{THEORETICAL FRAMEWORK}

Hedley Bull, a prominent representative of English School and Order, regards international society as an influential concept that emphasises that states can create order against anarchy. Bull elaborates that if states are willing to alter the anarchic structure, they must be willing to form a mechanism based on rules, norms, and institutions. This structure is called "Order" (Bull, 2012: 34, 38, 83). He further proposed three significant aspects in maintaining order: (1) a common binding interest among the states. (2) Rules, norms, and institutions in the framework of common interests. (3) Functional elements include the balance of power, international law, diplomacy, war, and great powers (Bull, 2012:34, 38, 83).

Similarly, Bull argues that the unitary actor who can ensure order and the formation of society is the sovereign state (Alderson \&Hurrell, 2000). The English School seeks to formulate rules and norms through international organisations for all the member states to rationally pursue their self-interests to pursue long-term peace and socio-economic development. The ES theorists believe that any disturbance in the system of sovereign states will disrupt the world order, and the results will be catastrophic (Watson, 1992).

\section{Concept of Order in English School}

To understand the concept of order, an understanding of the disorder is essential, which means chaos, instability, 
and unpredictability, which are not desired by the states (Bull, 2012: 3). The goals of an order may have basic, primary, and universal features aiming to limit violence, enforce conventions, protect property, and ensure survival (Bull, 2012: 4-5). The order permits actors to achieve their goals, whilst actors believe that progress is achieved through the positive and beneficial elements of the order.

Bull's order falls into three categories: order in social life, order at the international level -relations between states - and world order where humankind is incorporated (Bull, 2012: 4-5). Following this line, Bull claimed three sets of rules for creating an order. The first is 'will create order and live in it'. Order is created by states that are concerned with the creation and maintenance of order. The second rule is Coexistence; it emphasizes regulations of principles, supporting normative principles, the idea of order, and accepting other states' sovereignty and noninterference. The third rule is Cooperation; Cooperation among states leads to a transition from anarchy to hierarchy in the state system. Hence, Economic cooperation is as crucial as diplomatic ties vis-à-vis political and security concerns.

As per the ES, states must work in harmony while performing their duties related to the Order. Bull has explained different outcomes resulting from cooperation between actors, including maintaining international law, the balance of power, diplomacy, war, and the role of great powers (Bull, 2012: 4-5).

Firstly, Bull postulates that functionally, the balance of power ensures that states do not undermine order. It also protects the independence and sovereignty of the states against the great powers. The states' cooperation prevents the hegemony and dominance of the great powers. Hence the small states must maintain the balance of power through cooperation which is necessary in maintaining order (Alderson \&Hurrell, 2000;95-124). Secondly, by agreements and regulations, international law defines the rules of order, which specifies the basic principles of coexistence between actors, produces rules on conducting formal relations between states, and ensures compliance with the regulations (Bull, 2012: 188-189). Thirdly, diplomacy facilitates relations between states which are the members of an order. It enables countries to negotiate agreements, minimises disagreements, symbolising and actualising the order (Bull, 2012 188-189). Fourthly, war is described by many thinkers as a tool that can harness certain objectives. War can maintain the balance of power and can lead to positive change (Bull, 2012: 188189). Lastly, Great powers contribute to maintaining order by indulging states into an interaction that will maintain balance while preventing war chances. If the interests of great powers align with the interests of small powers, then order becomes permanent (Bull, 2012: 188-189).

\section{FROM ANARCHY TO ORDER IN SOUTHEAST ASIAN POLITICS}

International society theory has been criticised for not being able to fit in the current era. However, examples of its relevance are found in the contemporary world arena. Common interests and the anarchic environment were the elements that significantly impacted Southeast Asia after WWII. Jorgensen-Dahl proposed that, for states within the ASEAN, like Malaysia, Communism was the biggest threat. It propagated from China, with the notable success of the Communist Party of Burma, which resulted in the US intervention on Vietnam's soil. Indeed, from the US perspective, it was a tremendous strategic manoeuvre, and its efforts in Southeast Asia were an overspill from the Korean War (1950-1953) (Dahl, 1982; 70).

Communism was a tangible threat that was lingering throughout the Cold War (1945-1991). Irrespective of the Cold War concerns, another problem for ASEAN states was to maintain their sovereignty by eliminating the international and domestic threats, including border disputes, land claims, and political violence, which were undermining their authority as emerging postcolonial states (Ramcharan, 2000). Political stability was the core concern as these states imposed international sanctions on each other. However, Indonesia's sanctions on Malaysia regarding Konfrontasi (eresources.nlb, 2015), the Sabah problem between Malaysia and the Philippines (Malindog-Uy, 2020), and the border disagreements between Thailand and Malaysia gave rise to disputes, insecurity, and hostility.

Konfrontasi was a spark that led to the incorporation of security concerns within the region. These states shaped their relationships with other states in this axis of fear. States knew that this fear would harm both national unities and the perspective present in the outside world, further affecting the socio-economic situation. Hence, they desired to avoid the issues like Konfrontasi to bring harmony. 
In the 1950 s and 1960 s, internal stability was a core concern. Riots began and brought political unrest along with religious instability. Several reasons contributed to this situation. First was the sensitive political structure of the Southeast Asian states. The second was the internal insurgency, which included riots, political problems, and religious violence. In this entire situation, the states' administrations were blamed, which acquired new rules. Therefore, states developed new common interests according to the public demands, including a substantial economy, eradicating poverty, and boosting the economic interactions between countries. Moreover, a fear of great powers involvement also lingered upon the heads of Southeast Asian states. Therefore, the states came together to ensure security by removing disagreements, internal confusions, and Communism, which were the basis for foreign powers' intervention in Southeast Asia. The political, economic, and social anarchic environment and the common interest perspective created a 'stimulating effect' in the Southeast Asian states (Degelsegger, 2014).

\section{THE COOPERATION INITIATIVES IN THE REGIONAL SYSTEM - ASA (1961) AND MAPHILINDO (1963)}

Some Southeast Asia wanted to change the system from competition to cooperation and minimise an anarchic situation due to scattered interests. The Association of Southeast Asia between Malaysia, Thailand, and the Philippines, and the Malaysia-Philippines-Indonesia (MAPHILINDO, 1963) agreement was formed in this framework. Through ASA, states intended to reduce the communist influence, which was present in the agricultural community, while MAPHILINDO was formed to tackle the issues of foreign interference (Pollard, 1970). ASA and the MAPHILINDO tried to transform the situation but failed to uncover the common interests and values of the Southeast Asian states.

These states were unable to find a common interest that could keep interstate relations intact. For example, the ASA didn't include Indonesia, a strong state that holds a similar position as India does in SAARC. Thus, the exclusion of Indonesia from the regional platform depicts the weak foundation of the regional organisation. MAPHILIDO was also unable to preserve the relations between the states. During this period, the states were more inclined toward their national interests than common interests, as seen in the Sabah issue between Malaysia and the Philippines (Pitlo III, 2021). Like
Konfrontasi between Malaysia and Indonesia, there were other concerns in which the major powers were exploiting the aims of harmony (The Diplomat, 2016).

\section{THE FORMATION OF THE ASEAN REGIONAL ORDER}

After Indonesia, the Philippines, Singapore, Thailand, and Malaysia noticed their common interests and values. A significant practical transformation allowed states to establish the ASEAN based on their unique characteristics, norms, and needs within a common framework, which comprised the "ASEAN Way" (Aydın \& Demirbas, 2014). After deposing Sukarno, the US ally Suharto ended Konfrontasi and established peace with Malaysia. Both states recognised each other's sovereignty and legitimacy, and cooperation became critical in Indonesia's regional relations approach (Narine, 2006). Unlike the ASA, a positive change in the minds that emerged after the end of Konfrontasi was brought under the supervision of the Bangkok Declaration (1967) by the leadership of the Southeast Asian countries. It created a sense of realization that foreign bases have damaged the local identity and disturbed the ASEAN states' regional order and democratic stability.

Furthermore, in this period, the power struggle between the regional states and the sovereignty concerns of the member states were continuing, notably the struggle of the Indonesia-Malaysia-Singapore axis. A clever move by ASEAN states was not to remove the hold of great powers that would have escalated the Cold War. China and Vietnam held a hostile view towards ASEAN, so it was a significant diplomatic move under the Bull's order concept. Korea and Vietnam did not act the way ASEAN did, and its consequences were seen. The establishment of different institutions was the outcome of the understanding of states that a positive attitude is required for the region's progress. Moreover, instead of bilateral relations, they must opt for multilateral relations.

The inevitability of the ultimate US withdrawal from Vietnam would leave the ASEAN states potentially vulnerable to the spill-over of conflict from the resurgent communist regime in Vietnam. The actions of the great powers made member states realise that they must evaluate their security phenomenon within the framework of regional order rather than bilateral security relations.

Changes, including the Vietnam War and the rise of 
Japan, revealed that the ASEAN states were required to make normative arrangements to maintain the status quo and pursue their mutual self-interest in socioeconomic development. Member states began to think that they must create a peaceful regional environment to positively achieve national transformation and strengthen national cohesion. Under the ASEAN's perspective, these states came forward as a coherent unit to limit the political influence of foreign interests in the Southeast Asian region by making few requests to the great powers (Shafie, 1992: 44-46). First, they should respect Southeast Asia as a neutral region and keep the development perspective to maintain harmony. Second, they should not involve Southeast Asia in global politics. Third, they should give guarantees on neutrality.

\section{Creation of ZOPFAN (1971)}

ASEAN states formed the Zone of Peace, Freedom, and Neutrality (ZOPFAN) to specify the position of great powers in the region. ZOPFAN decided that the ASEAN members will not interfere in external conflicts and will not enter into any treaty that favours the regional order. Nuclear activities were also banned, along with the removal of foreign bases (ASEAN, 2012). By following these two objectives through the platform of ZOPFAN, ASEAN states showed an increase in the harmony of interests. Hence, it became a way towards maintaining peace at the international level by having friendly ties with states outside the region.

\section{ASEAN in the post-Cold War era}

The Post-Cold War era added further complexity to the Southeast Asian region. ASEAN decided to add more members to speak on behalf of the whole of Southeast Asia. Following the trend, Vietnam joined in 1995, followed by Myanmar and Cambodia in 1997 and 1999, respectively, which bolstered the importance of ASEAN as a regional organisation. Moreover, ASEAN introduced the ASEAN Free Trade Area (AFTA), which boosts foreign exports (Asean Briefing, 2014). In 1994, it created ASEAN Regional Forum (ARF) to discuss the regional security problems that have now expanded to 24 members. After the 1997-99 crises, ASEAN again introduced different reforms to maintain its effectiveness to sustain order and promote regional integration (Ortuoste, 2000).

Recently, ASEAN plans to create an economic and security complex (Parliament of Australia, 2021). The regional order of ASEAN has been pluralistic, and it has remained successful in complying with all the institutional frameworks highlighted in Bull's order concept. So far, it has successfully used international law and diplomacy to counter great power roles, which eventually promoted regionalism. Similarly, the principles of non-intervention and peaceful resolution of the conflict have been a great success of ASEAN.

\section{FORMATION OF SAARC}

SAARC was established on December 8, 1985, with its headquarters located in Kathmandu, Nepal. The association aimed to address the common issues faced by South Asian states, gear economic growth, cultivate cordial relations, and develop mutual understanding among the member states. Unfortunately, even after decades, the organisation cannot achieve its objectives due to interstate conflicts, Indo-centric threat perceptions, lack of cooperation, and a vast tapestry of cultures in South Asian countries. Nevertheless, this initiative to promote regional integration of South Asia was taken by Bangladesh's President Zia Ur Rahman on May 2, 1980 (Haider, 2012). The discussion for the formation of SAARC was held in three conferences at New Delhi, Baguio, and Colombo, respectively. Its seven founding members include Bhutan, Maldives, India, Sri Lanka, Bangladesh, Pakistan, and Nepal, while Afghanistan joined the organisation in 2007. While the US, Australia, China, Japan, South Korea, Myanmar, Mauritius, Iran, and the European Union holds the observer's status.

\section{ASEAN AND SAARC: A COMPARATIVE INQUIRY}

The objectives of both of these organisations aim to promote peace, stability and create opportunities for cooperation, but in this process, ASEAN is clearly on a jumpstart. ASEAN states have owned their organisation and have set the stage for multilateral decision making. On the other hand, SAARC has failed to work in harmony for mutual interests. Despite some short initiatives that have been taken, the internal rivalry has made the progress of SAARC stagnant.

A major difference between SAARC and ASEAN is that SAARC states believe in the concept of absolute sovereignty of the Westphalian model (Pattanaik, 2006). Therefore, SAARC members try to disregard the promotion of regionalism in South Asia. SAARC countries have taken some bilateral efforts, but no mutual consensus could be reached that could be regarded as a 
major success for the region.

However, ASEAN states have a clear aim for the organisation rather than having scattered individual ambitions as of India in South Asia. The unwillingness of the largest state in the region, India, is a major hurdle to the cordial working of SAARC due to its hegemonic desires (Amgain, 2016). Moreover, India has border issues with all states, except for the Maldives and Sri Lanka. Almost all the states have shown the desire to solve border disputes. However, India wants the resolution on its terms and has not allowed the United Nations (UN) as a third-party mediator to solve the regional problems.

Likewise, SAARC has failed to maintain a balance in the military and politico-economic sphere in the region. In the Pre-Cold War era, the alignment of different states and then the disintegration of the alliance had altered the balance of power in this region. Later, the nuclearization concept has been under discussion since India and Pakistan did not opt to sign the NonProliferation Treaty (NPT)(Miller \&Scheinman, 2021). On the other side, ASEAN had a consensus on declaring ASEAN a "nuclear-free zone". Due to such initiatives of the platform, the cooperation element has been promoted, and a spillover effect is generated.

Moreover, the imbalance in regional cooperation in South Asia is due to different secessionist movements. Pakistan and India separated based on different ideological beliefs; Sri Lanka has been subject to Tamil insurgency for a long time, and Bangladesh parted from Pakistan in 1971. Hence, one can regard the reason for the lack of performance of SAARC due to the mistrust and counternarratives existing in each state against the other.

Contrarily, the ASEAN is located within a more geopolitically compact space. The states, unlike SAARC members, are more homogenous in their political and security outlook, including their common fear of indigenous communist insurgencies. ASEAN members gained collective international prominence through their diplomatic efforts to oppose the Vietnamese invasion of Cambodia and to seek a political solution to the conflict (Giacoma, 2011).

On record, analyses portray those countries under SAARC have seen foreign blessing as a better opportunity and have cooperated with external powers to achieve their interests. They have never tried to hold hands to improve their position because of increased hostility between India and Pakistan which remain as dominant players in this organization. On the other hand, the ASEAN states have always looked inwards. As discussed earlier, ZOPFAM conveys to the external powers the latter's role in the region. Furthermore, "ASEAN Way" is a clear message that the members want to prosper in their way, with their norms and identity (Yunling, 2011: 231-237).

ASEAN's members have emboldened trust and mutual harmony that has created solidarity among them. By contrast, South Asian states hold divergences on many significant issues. South Asian countries have not established any consensus on central norms. Due to this lack of mutual agreement, the region is regarded as a "region without regionalism" (Hewitt, 1992: 75). Moreover, the peculiar thing about SAARC is that it was formed with the consensus of small powers, notably Bangladesh. Its formation worried India that this forum would wield a combined pressure on New Delhi regarding contradicting issues. It was also widely believed that an external hand might influence and harm Indian interests (Dixit, 1996: 383-384). All in all, India's dissatisfaction with SAARC is due to its clashing views with Pakistan on regionalism.

Unlike ASEAN's model of mutual consensus, SAARC can't achieve its potential due to the lack of consensus among members states, notably India, which sees no spot for regional integration unless the member states recognize its dominance in the region. Moreover, President Musharraf, while addressing SAARC members in 2004, stated that: "SAARC will never achieve its full potential; unless the dispute and tensions that draw us apart are resolved peacefully" (Malik, 2005). The working of SAARC depends a lot on India, a prime example of which was the 2016 SAARC summit in Pakistan, which India boycotted along with Afghanistan, Bangladesh, Nepal, and Bhutan. It reflects how the working of SAARC depends largely on the Indian stance in the region (INDIA TODAY, 2016). Furthermore, in contrast to ASEAN, SAARC has not been among the priorities of the regional states. Despite the enchantment shown by President Zia Ur Rahman, no other individual was ambitious to drive the SAARC that led to the disappointment of the association in reaching its expectations (Malik, 2005).

FACTORS DETERMINING ASEAN AND SAARC'S EFFECTIVENESS IN CONFLICT MANAGEMENT ASEAN

ASEAN holds a preventive approach towards conflict 
management. It believes that disputes should not be exaggerated to the level where resort to force is the last option. A criticism of ASEAN states is that they are content with circumnavigating rather than settling or resolving disputes. However, their minimalist approach has prevented any violent confrontation among member states. Mely Anthony explains that the types of mechanisms for reconciliation found in ASEAN are geared toward conflict prevention. These mechanisms are referred to as the "ASEAN Way" of diplomacy and accommodation that have been reinforced by the careful cultivation, socialisation, and adherence to regional norms (Mely, 2002: 540).

The strategy of the mutual consensus model has functioned well. Consensus between ASEAN members is not like a perfect agreement but the shrewd tactic of "consensus minus $X$ " that has dealt with the lack of complete harmony. It permits a member to refrain or determine and let the refraining members be carried without any restraint, courtesy of a pattern. This is apparent in the ASEAN Free Trade Area (AFTA) that encourages flourished economies to adopt the scheme. At the same time, CLMV (Cambodia, Laos, Myanmar, and Vietnam) members are granted time-space to bring reforms to their economies.

Moreover, several doctrines exist regarding decisionmaking norms. Firstly, no issue is put forward until the mutual consensus of all members. Hence, contentious issues are put on hold in the absence of consensus. Secondly, members overtly show a united front in the resolution of conflict. Thirdly, a course of consideration incorporating sessions, conciliation, and concessions exists. Fourthly, the "lead state" concerned critically with the issue holds an influential say and is allowed to lead. Finally, bilateral issues are solved under provisions of the high council, but third-party mediation is seen as less risky to ASEAN's harmony (Kripa, 2008: 262). However, in 2005, the land retrieval issue between Singapore and Malaysia was settled without enmity by the International Tribunal of Law of the Sea (pca-cpa, 2021). The ASEAN incorporates conflict avoidance doctrine, but it does not mean that it lacks formalised law-backed mechanisms regarding conflict resolution. The set of binding agreements and treaties of the ASEAN greatly emphasises regional security and cooperation. It includes the ASEAN Concord, the Treaty of Amity, the Zone of Peace, the Freedom and Neutrality Declaration, the Treaty on Southeast Asia nuclear weapon Free Zone
(SEANWFZ). Hence, it indicates that formal and informal elements intertwining are required for regional safety and peace.

The ASEAN's founders have remained intensely concerned with regional security, albeit they have not established a formal structure for regional reconciliation. However, they desire to cultivate a zeroconfrontation environment. Sridharan indicates that the ASEAN is not a formal security arrangement but an attempt by six non-communist states to stabilise the region by establishing a regional entity and promoting behaviour for peaceful settlement of disputes (pca-cpa, 2021). Self-restraint, de-escalation, and non-threatening behaviour have been the main ingredients of conflict management in the ASEAN region.

Moreover, in the environmental and economic crises and East Timor crisis in the 1990s, ASEAN responded weakly while addressing the real issues. However, in the Cambodian political crisis, ASEAN was forced to form a Troika of ASEAN foreign ministers to seek a diplomatic settlement for the problem. The Cambodian government expected this Troika mission as a way towards its admission in ASEAN. However, when it became obvious that its admission was delayed, the Cambodian government condemned this mission for interference in its domestic matters. Despite this experience, the member states agreed to establish the ASEAN Troika as an ad-hoc body to cooperate on regional peace and stability issues closely (ASEAN Secretariat, 2021). Furthermore, Troika comprised former, present and future foreign ministers to settle the regional disputes with zero interference in domestic politics of member states. ASEAN structure relies on informal means, which deals with alteration at the bilateral level. Thus, the rare use of regional machinery in tackling disputes is undoubtedly a fault, but norms settled by ASEAN have contributed much to avoid violent conflicts.

\section{SAARC}

Unlike ASEAN, which has been successful in conflict management, SAARC is immune from formal and informal patterns to avoid conflict by not resorting to coercive measures. It depicts the lack of consensus between South Asian countries. All SAARC decisions are based on concord, and Article X (2) of the charter which explicitly excludes the bilateral contentious issues (Charter of SAARC). Therefore, there exists no agreement $\mathrm{t}$ that paves the way to regionalism. Moreover, while conferring bilateral issues, the 
continuous retreats on annual summits have been utilised to address differences between member states.

Addressing bilateral issues on side-line meetings rather than summits have rarely cooled the heat on bilateral deadlocks as done after 1998 nuclear explosions carried out by Pakistan. India-Pakistan dialogues have been disappointing for most times and were sabotaged by unpleasant events, i.e., Mumbai attacks and the Samjhota Express incident. Moonis Ahmar analyzed the contingencies among the arch-rivals as: "Lack of political will within Indian and Pakistani regime to ameliorate bilateral ties on the basis of equality and peaceful coexistence exacerbated historical cleavages and political and religious mistrust between the two countries" (Mallik, 2013).

Since the inception of SAARC, South Asian states knew that regional cooperation would be impossible without the settlement of bilateral issues. New Delhi opposed this idea as it claims that the SAARC charter should exclude contentious bilateral issues from discussions at all levels. India believes that the inclusion of bilateral issues in the SAARC charter will cause more harm than good. Moreover, India fears that this forum will jointly exert pressure on her that will harm the Indian interests in the region. Similarly, Bangladesh is also in favour of the exclusion of bilateral issues. By contrast, other South Asian states, notably Pakistan, preoccupied with the Indo-centric threat perception, believe that the absence of peace and conflict resolution mechanism makes regional cooperation futile. The bilateral diplomatic tracks are ineffective within and outside SAARC. Occasionally, the energies exerted by Nawaz Sharif for normalisation and revision of bilateral dialogues were met by the hard-liner factors in the establishments of both sides. Similarly, the highly nationalist posture under the majoritarianizm of Narendra Modi also mounted strong opposition to it.

Failure on formal diplomatic fronts has provoked the need to encourage the informal channels that will pave the way for reviving official channels. Such informal channels include cricket diplomacy, transnational ties, and cultural exchanges. Furthermore, through the perspective of Sociological Liberalism, the conduct of the trans-border network and employing Burton's concept of the cobweb model will improve the ties between regional countries and bridge the way towards regionalism(Burton, 1984). Moreover, the multi-track diplomacy, which includes the people belonging to different occupations as MaulanaFazal Ur Rahman of JUI, has followed multi-track diplomacy by frequently visiting India and emphasising peace (Idrees\&Ayaz, 2015: 400-408). New Delhi always stressed SAARC to pursue multi-track diplomacy to ensure mutual understandings. The diplomatic channels have served as an important tool of bargaining in side-line meetings of SAARC. Pakistan has stressed creating a conflict resolution mechanism in the association. Even the delegations of Bangladesh, Nepal, and Sri Lanka have raised their concerns and position on political issues with India.

Despite the desire of member countries to include bilateral issues, New Delhi discourages such aspirations due to her regional interests. Sri Lankan Foreign Minister suggested evaluating mechanisms that will hold secret foreign ministers' meetings, where issues could be discussed. SAARC, therefore, must not end as a dumb, blind, and deaf association (Idrees \& Ayaz, 2015: 403). Pakistan, Nepal, and the Maldives frequently endorsed the proposal to settle the unsolved disputes in the region. According to Gooneratn, South Asian countries are involved in security cooperation with other regional organisations, including ASEAN and Shanghai Cooperation Organisation (SCO) (Gooneratne, Inayat, Khan \&Swaran, 2007). This will help them to cooperate and formulate a mechanism to discuss security-related issues. Naik emphasised that "A South Asian security forum" should be established to discuss political and security related issues (Naik, 1999). Regardless of thestrong positions regarding the charter, no concrete settlement of disputes has been done so far. Nevertheless, SAARC mainly addresses economic or functional issues rather than hard-core political and territorial disputes. This proves the limited performance of SAARC and its blurred effectiveness.

\section{RECOMMENDATIONS FOR SAARC}

Despite the failure to solve an interstate conflict, a chance of improvement in SAARC exists. A region needs to hold a common stance, just as Pakistan and India maintained the non-interference of any external power after independence. Similarly, South Asia must use SAARC's platform as a binding force to address common issues like trade, technology, security, and international peace. In most cases, it is seen that diplomats already have a summit statement in SAARC. So, instead of finding 
a common statement, they stick to personal agenda without giving any room for common interest to prevail. But other than the change in political agenda, the institution needs to undertake structural and socioeconomic changes that will compel states to put their faith in SAARC.

\section{Structural Recommendations}

Changing dynamics in South Asia requires SAARC to decide the future of Article $\mathrm{X}$, whether they want to solve bilateral issues or not. The world knows that the reason for SAARC being ineffective in conflict management is the Pakistan-India rivalry. Therefore, SAARC must try to lessen the intensity of this rivalry and ensure that India and Pakistan can live like regular neighbours.

- The structure of the secretariat requires changes in its foundations by making it more responsive. The size must be increased through which a quick implementation of policies will be possible.

- The decision of SAARC must be based on the majority rather than unanimity. It requires a change in the SAARC's charter for further enhancing the functioning of the platform.

- A vivid response from the Secretary-General is required by indulging in conflicts within the region, for which meetings must be conducted with topmost government officials.

- Issues taken by the SAARC under the Integrated Programme of Action (IPA) require an increase in each state's funding. The funding must also include $1 \%$ of the defence budget of each state, by which a better working of SAARC will be possible.

- A SAARC's parliament must be established. As an achievable aim, the formation of the SAARC's assembly can be envisaged. This assembly, to begin with, may only have functions of deliberation and not legislative functions.

- An increase in government officials' interactions is required for which at least three summits of foreign ministers must be conducted.

- Ministers holding other portfolios must have frequent interactions to tackle regional concerns.

- Freedom of the secretariat of SAARC is important. States must give freedom to the secretariat to tackle minor issues by giving their consent. With time, when states see the resolution of smaller conflicts by SAARC, they will build trust in the organization, which will help SAARC to flourish.

\section{Socio-economic Recommendations}

In the current global arena, the strategic cards are linked to the economic growth of a region. To defuse tensions in South Asia, economic measures must be initiated. Thus, a change in vision is required. For SAARC to be owned as the face of South Asia, the following recommendations are proposed:

- The promotion of economic interdependence and the smooth working of the South Asian Free Trade Area (SAFTA) and SAARC Preferential Trading Arrangement (SAPTA) depend on the PakistanIndia rivalry's status. Therefore, it must be resolved through an effective conflict resolution mechanism.

- The SAARC's secretariat must control the role of great powers to focus on inward solutions to regional conflicts.

- Summits for conflict management must be convened regularly.

- To keep the people-to-people contact aligned, SAARC universities must be established. Such universities should have campuses in all SAARC member states, which will increase transnational relations.

- The initiatives like Samjhota Express must be initiated. Such steps will increase regional convergence, expanding to sea routes such as Karachi, Chabahar, and Gwadar.

- Good economics is never bad politics. Special Economic Zones (SEZs) must be established to promote free trade. The economic corridor can be introduced within the region under SAARC.

- A South Asian security organization must be established to deal with terrorism, drugs, and arms trafficking, which will help in conflict management. The organization will also help resolve other regional concerns like poverty, illiteracy, environmental degradation, diseases, and economic disparity.

- A "Made in South Asia" motto is important, just like "ASEAN WAY" to promote regionalism.

- SAARC must monitor policy changes at the regional level. For instance, tariffs, trade, and other economic policy prescriptions must be brought under SAARC's monitoring, just like ASEAN, which has built the ASEAN free trade area (AFTA) platform for such initiatives. 
- SAARC must be the face of tackling challenges to globalization in the region. SAARC initially needs to take a short initiative, which will create harmony between states and increase interdependence, generating a spillover effect.

- If small steps are initiated in the education sector, infrastructure and air travel facilities can occur. Take the example of air routes; if Pakistani airlines want to reach Kathmandu, they first must go to Dhaka or Bangkok. After that, they can reach Kathmandu. Similarly, the student exchange programs must be initiated by SAARC to promote people-to-people contact, which will help image building.

- A road transited between Nepal, and Bangladesh should be allowed to flourish, for which SAARC has a vital role to play. Such joint ventures are essential. SAARC must promote the venture of a joint economic collider in the region, which will strengthen the role of South Asia in world politics

The creation of SAARC was a hallmark, but with time it has not proven to be an effective organisation by failing to create harmony between states. It aimed to build common norms, but it has failed to integrate its members' interests for more than two decades of its foundation. Nevertheless, the association proves that its members want to cooperate to promote regionalism. SAARC holds enormous potential, and one cannot ignore the opportunities that the region has to offer. Hence, the way to a better South Asia depends on SAARC.

\section{CONCLUSION}

The main point to conclude is that both the ASEAN's and Bull's view of order is that an anarchical society has some features, of which the main aim is to promote and preserve the international order. Order can be defined as a pattern to preserve certain goals. ASEAN has been successful in maintaining order. A sharp distinction between the two regions can be made by understanding Hedley Bull's categorisation of the state system into two groups: a system of states and a society of states. Both have a different standing in the international realm. Within this categorisation, SAARC falls under the system of states and ASEAN under the type of society of states. Harmony in the society of states depends upon the type of interaction and communication they have. Diplomacy is the way through which states interact with each other. Diplomatic instruments used by states show their willingness for peaceful operations between them. States have acquired means of communication to avoid friction and cement relations, as done by ASEAN to manage the peaceful management of conflicts. While South Asian states have been unsuccessful in keeping their interests aligned. Each state is on its own, whereas ASEAN states have formed a society of mutual trust and are working in harmony by keeping their interests aligned. SAARC is in the primitive stage, because of which even the routine procedures are subject to getting postponed or cancelled. This is why SAARC is far from having a rulebased behaviour that is at the core of the society of states, as narrated by Hedley Bull.

Pakistan and India have used SAARC to keep their rivalry alive and have failed to mend relations. None of them has helped SAARC reach even its minimal potential despite being the region's strongest powers. The future of the effectiveness of SAARC depends upon the diplomatic stance that Pakistan and India will take to keep their past separate and work for regional stability. On the other hand, ASEAN must be given credit for embracing a mechanism to reduce conflicts. Though ASEAN was not explicitly established for conflict management, it has become a cooperative security regime. SAARC, contrarily, has not been able to work to reduce any conflict. The region still comprises states in conflictual ties with each other where the use of force is still an instrument of foreign policy. Regionalism is a long route for the SAARC members as the region is yet to cross the Rubicon. Considering the effectiveness of the organisation, SAARC still lacks unity and coherence. In contrast, ASEAN is on the right path. It is comparatively more effective in its dealing with interstate conflicts than SAARC.

\section{REFERENCES}

Alderson, K. \&Hurrell, A. (1966). The Grotian Conception of International Society (1966). Hedley Bull on International Society, 2000, 95-124. https://link.springer.com/chapter/10.1007/9781-349-62666-3 5

Agreements. (2014, February 13). ASEAN Briefing. https://www.aseanbriefing.com/news/understan ding-aseans-free-trade-agreements/.

ASEAN at 30: Enlargement, Consolidation and the Problems of Cambodia - Parliament of Australia. (N.d.)Parliament of Australia https://www.aph.gov.au/About_Parliament/Parli 
amentary Departments/Parliamentary Library/P ublications Archive/CIB/CIB9798/98cib02.

Amgain,S. (2016). Regional Hegemony in South Asia a Study of Nepal-India Relation. Norway:Norwegian University of Life Sciences, 196.https://nmbu.brage.unit.no/nmbuxmlui/bitstream/handle/11250/2435232/Sujan \%20Amgain $\% 20 \% 202014-$ 2016.pdf?sequence $=2 \&$ isAllowed $=y$.

AamirMalik,H. (n.d.) Musharraf Calls for Trust Between SAARC Nations. Arab News. last modified January 1 , 2005 , https://www.arabnews.com/node/242567

ASEAN 2000. (n.d.). The ASEAN Troika: Terms of Reference. ASEAN Secretariat, Accessed January 18, 2021, http://www.aseansec.org/3637.htm.

Bull, H. and Hurrell, A. (2012).The Anarchical Society: A Study of Order in World Politics. Columbia University Press.

Blanco Pitlo III, L. (2021, January 30). The Sabah Issue and Its Impact on Philippine-Malaysian Relations," CSS Blog

Network.https://isnblog.ethz.ch/internationalrelations/the-sabah-issue-and-its-impact-onphilippine-malaysian-relations.

Consuelo C. Ortuoste, M. (2000, September 27). Center Occasional Paper - SLOC Security in the Asia Pacific. APCSS. https://apcss.org/Publications/Ocasional\%20Pap ers/OPAseanForum.htm.

Caballero-Anthony, Mely. (2002). Partnership for Peace in Asia: ASEAN, the ARF, and the United Nations. Contemporary Southeast Asia 24, no. 3, 540.

https://www.researchgate.net/publication/2903 14633 Partnership for Peace in Asia ASEAN the $\underline{A R F}$ and the United Nations

Cases | PCA-CPA. (n.d.) pca-cpa.org, accessed January 29, 2021. https://pca-cpa.org/en/cases/108/

Charter of the south asian association for regional cooperation

(SAARC).

SAARC.http://www.internationaldemocracywatch .org/attachments/436 Saarc Charter.pdf.

Della-Giacoma, J. (n.d). Preventive Diplomacy in Southeast Asia: Redefining the ASEAN Way. International Crisis Group, https://www.crisisgroup.org/asia/south-eastasia/preventive-diplomacy-southeast-asia- redefining-asean-way.

Dixit, J. N. (1996). My South Block years: Memoirs of a Foreign Secretary. Bangalore: UBS Publishers Distributors, 383-384.

Degelsegger, A. et al. (2014).Spotlight On: Stimulating Innovation in Southeast Asia. Centre for Social Innovation (ZSI).

Eresources.nlb. (2015, December).Indonesia Announces Konfrontasi (Confrontation) - Singapore History.https://eresources.nlb.gov.sg/history/eve nts/126b6b07-f796-4b4c-b658-938001e3213e

Gooneratne,J. (2007). Sri Lanka and Regionalism. In Regionalism in South Asian Diplomacy. Edited by Alyson J. K. Bailes, John Gooneratne, MavaraInayat, JamshedAyaz Khan and Swaran Singh, SIPRI Policy Paper No. 15, Stockholm, 5467.https://www.sipri.org/publications/2007/sipr i-policy-papers/regionalism-south-asiandiplomacy

Haider, M. (2012, December 8). SAARC: A Pipedream of Assassinated Leaders. DAWN. https://www.dawn.com/news/769864/saarc-apipedream-of-assassinated-leaders

Idrees, M. \&Ayaz,M. (2015). Peace and Conflicts in South Asia: A Case Study of Pakistan and India. International Journal of Political Science Development 3, no. 10, 400408.https://www.researchgate.net/publication/3 34729421 Peace and conflicts in South Asia A C ase Study of Pakistan and India

Jorgensen-Dahl,A. (1982). Regional Organization and Order in Southeast Asia. UK: Palgrave Macmillan: 70.

K. Pollard, V.(1970). ASA and ASEAN, 1961-1967: Southeast Asian Regionalism. Asian Survey 10(3), 244-255. doi:10.1525/as.1970.10.3.01p0570o.

Malindog-Uy, A. (2020, November 25). Sabah: A Dispute That Refuses to Go Away.The ASEAN Post.https://theaseanpost.com/article/sabahdispute-refuses-go-away.

Marston Hewitt, V. (1992). The International Politics of South Asia. Manchester: Manchester University Press: 75

Mallik, S. (2013). Track-II Diplomacy and its Impact on Pakistan-India Peace Process, Current Affairs, 31(4-1), 215225.https://www.jstor.org/stable/48527640

Miller, M. \&Scheinman, L. (n.d.). Israel, India, and 
Pakistan: Engaging the Non-NPT States in the Non-proliferation Regime.Arms Control Association. Accessed January 12, 2021, https://www.armscontrol.org/act/200312/features/israel-india-pakistan-engaging-nonnpt-states-nonproliferation-regime.

Naik, N. A. (1999). SAARC-From Association to Community: Prospects and Problems. South Asian Survey $6(2)$,

33343.https://journals.sagepub.com/doi/10.1177/09 7152319900600213

Narine, S. (2006). The English School and ASEAN.The Pacific Review, 199 218.https://www.tandfonline.com/doi/abs/10.10 80/09512740500473247?journalCode $=$ rpre20

Ramcharan,R. (2000,April). ASEAN and NonInterference: A Principle Maintained," Contemporary Southeast Asia 22, 60-88. https://www.jstor.org/stable/25798479.

SAARC: Maldives Joins India, 4 Others in Boycott; Pak's Isolation Complete. (n.d) India Today, https://www.indiatoday.in/world/story/saarcsummit-maldives-joins-india-pakistan-isolationcomplete-344244-2016-10-01.

Pattanaik, S. S. (2006, Jan-Mar).Making Sense of Regional Cooperation: SAARC at Twenty.Strategic Analysis $30(1)$, 139 160.https://idsa.in/system/files/strategicanalysis spattanaik 0306.pdf.

Sridharan, Kripa. (2008, March).Regional Organisations and Conflict Management: Comparing AseanandSaarc. Regional and Global Axes of Conflict, 262. http://citeseerx.ist.psu.edu/viewdoc/download;jsession id=6E82FC9D08607FD8066117DA80F78FAE?doi $=10.1 .1 .599 .6418 \& \mathrm{rep}=\mathrm{rep} 1 \&$ type $=\mathrm{pdf}$

ŞekerAydın, G \&EminDemirbas, C. (2014). BirÖrgütlenmeÇerçevesiOlarak ASEAN Yolu'nunBaşarısı.UluslararasiHukukvePolitika10(3 7),

71-107. https://www.academia.edu/9025204/Bir \%C3\% 96rg\%C3\%BCtlenme \%C3\%87er\%C3\%A7evesi Olarak ASEAN Yolunun Ba\%C5\%9Far\%C4\%B1s $\% \mathrm{C} 4 \% \mathrm{~B} 1$.

Shafie (1992).Neutralisation of Southeast Asia. In B. A. Hamzah (Ed.), Southeast Asia and Regional Peace: A Study of the ZOPFAN," ISIS, 44-46

Treaty on the Southeast Asia nuclear weapon-Free Zone. (2012, May 11 $1^{\text {th }}$. Association for Southeast Asian Nations

(ASEAN).https://asean.org/?static post=treatyon-the-southeast-asia-nuclear-weapon-free-zone.

The Diplomat. (2016, September 16). The War That Gave Birth to

ASEAN.https://thediplomat.com/2016/09/thewar-that-gave-birth-to-asean/.

W. Burton, J. (1984). The Domestic Sources of International Crisis. Global Conflict

Watson, A. (1992). The Evolution of International Societies: A Comparative Historical Analysis. London; New York: Routledge, 299-310.

Yunling, Z. (2017). ASEAN at 50: A Valuable Contribution to Regional Cooperation. Asean @ 50,1(37), 231237. $\quad$ https://www.eria.org/asean50-vol.137.zhang-yunling.pdf.

Publisher's note: EScience Press remains neutral with regard to jurisdictional claims in published maps and institutional affiliations.

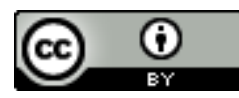

Open Access This article is licensed under a Creative Commons Attribution 4.0 International License, which permits use, sharing, adaptation, distribution and reproduction in any medium or format, as long as you give appropriate credit to the original author(s) and the source, provide a link to the Creative Commons license and indicate if changes were made. The images or other third-party material in this article are included in the article's Creative Commons license, unless indicated otherwise in a credit line to the material. If material is not included in the article's Creative Commons license and your intended use is not permitted by statutory regulation or exceeds the permitted use, you will need to obtain permission directly from the copyright holder. To view a copy of this license, visit http://creativecommons.org/licenses/by/4.0/.

(C) The Author(s) 2021. 